logos_i_ethos_2016_(40)_numer_specjalny_1, s. 123-141

DOI: http://dx.doi.org/10.15633/lie.1703

\author{
Barbara Koc-Kozłowiec \\ Wyższa Szkoła Ekonomii i Innowacji w Lublinie
}

\title{
Szczęście i perspektywa postrzegania czasu
}

Szczęście jest jednym z kluczowych pojęć dotyczących sfery życia społecznego i etycznego. Dowodem na to może być fakt, że Zgromadzenie Ogólne Narodów Zjednoczonych na posiedzeniu plenarnym 19 lipca 2011 roku przyjęło rezolucję proklamującą dzień 20 marca Międzynarodowym Dniem Szczęścia. W rezolucji akcentowano, że dążenie do szczęścia jest podstawowym prawem człowieka ${ }^{1}$. Szczęście uznane zostało

Barbara Koc-Kozłowiec, dr, Wyższa Szkoła Ekonomii i Innowacji w Lublinie Pracownia Historii, Teorii Wychowania i Opieki. Zainteresowania naukowe: psychologia komunikacji, rehabilitacja procesów poznawczych i wykonawczych. Ważniejsze publikacje: Człowiek z zespołem apalicznym $w$ refleksji Jana Pawła II, [w:] Wychowanie do wartości w nauczaniu Jana Pawła II, red. T. Bogacka, M. Żmigrodzki, Lublin 2009; Treningfunkcji poznawczych u osób w okresie późnej dorosłości, [w:] Kształcenie przez całe życie, perspektywy i nadzieje, red. R. Adamczewski, J. Swędrak, Kraków 2014.

wraz z dobrobytem za uniwersalny cel w życiu każdego człowieka, a co za tym idzie - zaznaczono, że powinno być traktowane na równi $z$ dążeniem do dobrobytu, jako główna wytyczna planowanej i realizowanej przez współczesne rządy polityki społecznej. Rezolucja zawiera również tezę o potrzebie bardziej sprawiedliwego i zrównoważonego rozwoju poprzez osiąganie wzrostu gospodarczego, a także likwidację ubóstwa i dążenie do szczęścia i dobrobytu wszystkich narodów ${ }^{2}$.

1 Resolution adopted by the General Assembly on 28 June 2012, General Assembly, A/RES/66/281, http://www.un.org/ga/search/view_doc.asp?symbol=A/RES/66/281 (15.05.2015). Podobne w treści sformułowanie znalazło się w proklamowanej 236 lat wcześniej amerykańskiej Deklaracji Niepodległości.

2 R. Layard, Why happiness should be a global priority?, http://www.huffingtonpost.co.uk/ richard-layard/why-happiness-should-be-a-global-priority_b_2900256.html (16.05.2015). 
Od ponad trzydziestu lat na całym świecie są prowadzone badania na temat czynników wpływających na odczuwanie szczęścia (szczęście badane jest $z$ perspektywy jednostek i społeczeństw) ${ }^{3}$. Zasadnicze znaczenie mają oczywiście czynniki ekonomiczne i osobiste, a zarazem społeczne i środowiskowe. Nie ulega wątpliwości, że fundamentalną rolę odgrywa poziom dochodu narodowego, a bieda pozostaje nadal główną przyczyną nieszczęśliwego życia. Czynnikiem osobistym mającym wpływ na poczucie zadowolenia jest perspektywa postrzegania czasu przez osobę. Podobnie jak czas obiektywny, czas psychologiczny - postrzegany indywidualnie - odnosi się do przeszłości, teraźniejszości i przyszłości. Odnoszenie się przez człowieka do określonych perspektyw czasowych ma wpływ na odczuwanie przez niego zadowolenia (szczęścia).

\section{Szczęście - istota pojęcia}

$\mathrm{Na}$ temat istoty szczęścia napisano bardzo wiele w ciągu minionych epok, aż po czasy współczesne. Na gruncie nauki polskiej Władysław Tatarkiewicz opisywał pojęcie szczęścia w książce $O$ szczęściu, w której podkreślał, że należy najpierw „wyjaśnić”, co znaczy słowo szczęście, aby móc potem mówić z sensem o szczęściu, ponieważ termin ten ma charakter wieloznaczny. Tatarkiewicz postrzega szczęście jako „zadowolenie z życia wziętego w całości” ${ }^{4}$. W powszechnym użyciu szczęście występuje w znaczeniu przedmiotowym (są to pozytywne wydarzenia, które kogoś dotykają) i podmiotowym (dodatnie przeżycia).

Starożytni Grecy określali mianem eudajmonii, czyli szczęścia, posiadanie największej miary dóbr dostępnej człowiekowi. Arystoteles z eudajmonią utożsamiał najwyższe dobro dostępne człowiekowi, wskazując, iż „różni ludzie utożsamiają szczęście z różnymi rzeczami w różnym czasie

3 M. Williamson, Improving wellbeing schould be our globar priority, http://www.huffing tonpost.co.uk/dr-mark-williamson/enhancing-human-wellbeing_b_3887498.html (16.05.2015).

4 W. Tatarkiewicz, O szczęściu, Warszawa 1962, s. 21. 


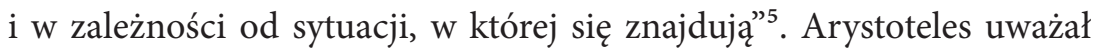
szczęście za byt obiektywny.

Szczęście jest aksjomatem faktycznie przeżywanym przez człowie$\mathrm{ka}$, jest pojęciem wielowymiarowym i tym samym staje się trudne do precyzyjnego zdefiniowania. Stąd w celu przybliżonej konkretyzacji tego terminu warto odwołać się do definicji słownikowych. I tak Słownik języka polskiego definiuje szczęście jako „pomyślny los, pomyślność, powodzenie"

Z rzeczownikiem „szczęście” związany jest czasownik „szczęścić”, opatrzony kwantyfikatorem „podniosły” . Odnosi się do kontekstów związanych z formami błogosławieństwa, obdarowania. Jest metaforycznym określeniem momentu, akcji, wydarzenia, procesu, któremu towarzyszy ofiarowanie daru (darzyć kogoś szczęściem, pomyślnością). Ukazuje także relacje między Bogiem a człowiekiem, polegające na tym, że Stwórca obdarowuje człowieka różnymi dobrami, których posiadanie w stopniu właściwym zapewnia dostatek i satysfakcję. Znaczenie semantyczne czasownika „szczęścić” obejmuje płaszczyznę duchowej i fizycznej egzystencji człowieka. W definicjach słownikowych szczęście w aspekcie etyczno-społecznym wyraża się mniej lub bardziej bezinteresowną chęcią realizacji dobra $\mathrm{w}$ takim stopniu, by dokonały się zmiany na lepsze lub takie, które nie przyczynią się do pogorszenia sytuacji. Szczęście ujawnia się więc w pozytywnej ingerencji, ukierunkowanej na dobro drugiego człowieka lub samego siebie, na spowodowanie stanu niebędącego zaprzeczeniem dobra ${ }^{8}$.

W ostatnich latach powstała dyscyplina naukowa - psychologia pozytywna - która zajmuje się między innymi przesłankami leżącymi u pod-

5 C. Lord, Arystoteles, [w:] Historia filozofii politycznej, red. L. Strauss, J. Cropsey, Warszawa 2010, s. 130.

6 Stownik języka polskiego, t. 3, red. M. Szymczak, Warszawa 1995, s. 373.

7 Uniwersalny słownik języka polskiego, t. 3, red. S. Dubisz, Warszawa 3003, s. 238.

8 M. Kaczor, Etyczno-społeczny wymiar pojęcia szczęście na podstawie definicji słownikowych, [w:] Szczęście w wymiarze pedagogiczno-socjologicznym, red. E. Kowalska, P. Prufer, M. Kowalski, Kraków 2014, s. 30. 
łoża dobrego samopoczucia i szczęścia ${ }^{9}$. Przedmiotem badań psychologii pozytywnej są kwestie związane ze szczęściem jednostki i społeczeństwa.

\section{Czas i kierunek upływu czasu}

Czas zaliczany jest do wielkości fizycznych, określających kolejność zdarzeń oraz odstępy między zdarzeniami zachodzącymi w tym samym miejscu. Jest wielkością skalarną, rozumianą jako trwanie, odcinek czasu, chwila oraz czwarta współrzędna czasoprzestrzeni w teorii względności $^{10}$. Do początku XX wieku ludzie wierzyli w czas absolutny. To znaczy uważali, iż każdemu zdarzeniu można jednoznacznie przypisać pewną liczbę zwaną czasem zdarzenia i że wszystkie zegarki pokażą taki sam czas między dwoma zdarzeniami ${ }^{11}$.

Dla Arystotelesa czas łączył się z ruchem. Święty Augustyn postrzegał czas jako bezcenny, związany ze światem materialnym, ze zmianą i przemijalnością. Immanuel Kant wskazywał na aprioryczność czasu i przestrzeni: „doświadczenie ukazuje zawsze przestrzeń i czas, jako realne; natomiast transcendentalna analiza, wskazuje, że są idealne" ${ }^{\prime 2}$. Według Issaka Newtona istnieje tylko jeden, uniwersalny i wszechobejmujący czas (czas absolutny), który płynie w jednostajnym tempie i nic nie wywiera na niego wpływu. Jest więc absolutny i obiektywnie jednakowy w całym wszechświecie ${ }^{13}$. Odkrycie, że prędkość światła względem wszystkich

9 J. Haidt, Szczęście. Od mądrości starożytnych po koncepcje współczesne, tłum. A. Nowak, Gdańsk 2007, s. 57. Powstanie nowej dyscypliny naukowej nastąpiło w wyniku prac Martina Seligmana, byłego przewodniczącego Amerykańskiego Stowarzyszenia Psychologów. Źródłem inspiracji były także publikacje przedstawicieli nurtu psychologii humanistycznej, do którego zaliczają się Carl Rogers i Abraham Maslow.

10 L. Cooper, Istota i struktura fizyki, tłum. J. Kozubowski i in., Warszawa 1975, s. 104. W fizyce klasycznej czas jest wielkością niezależną od innych wielkości oraz płynącą w tym samym rytmie we Wszechświecie. W mechanice relatywistycznej czas jest czwartą współrzędną czasoprzestrzeni i jego upływ zależy od obserwatora, czyli jest różny dla różnych obserwatorów.

11 Zdarzenie jest czymś, co zachodzi w określonym punkcie przestrzeni i w określonej chwili. Aby wyznaczyć zdarzenie, należy zatem podać cztery współrzędne. Można je wybrać dowolnie, czyli posłużyć się trzema współrzędnymi przestrzennymi i dowolną miarą czasu.

12 W. Tatarkiewicz, Historia filozofii, t. 2, Warszawa 2005, s. 192.

13 G. Białkowski, Stare i nowe drogi fizyki. Fizyka dnia dzisiejszego, Warszawa 1985, s. 422. 
obserwatorów jest ta sama, niezależnie od ich ruchu, doprowadziła do powstania teorii względności i porzucenia idei czasu absolutnego ${ }^{14}$. Zamiast tego każdy obserwator ma swoją miarę czasu w postaci niesionego zegara. Przy czym zegary różnych obserwatorów niekoniecznie muszą zgadzać się ze sobą. Czas stał się pojęciem bardziej osobistym - związanym $\mathrm{z}$ obserwatorem.

Nowe spojrzenie na czas dała szczególna teoria względności. Zgodnie z nią czas zależny jest od układu odniesienia, w którym się go mierzy (w układach poruszających się z prędkością światła czas płynie wolniej). Albert Einstein w ogólnej teorii względności dowodził, że czas nie płynie odrębnie, lecz jest związany jako czwarty wymiar w czasoprzestrzeni.

Czasowi nadajemy kierunek za pomocą strzałki czasu, czyli właściwości pozwalającej odróżnić przeszłość od przyszłości ${ }^{15}$. Istnieją co najmniej trzy strzałki czasu: termodynamiczna strzałka czasu (wiążąca kierunek upływu czasu z kierunkiem wzrostu entropii), psychologiczna strzałka czasu (związana z poczuciem upływu czasu przez człowieka, czyli z tym, że pamięta on przeszłość, a nie przyszłość) oraz kosmologiczna strzałka czasu (łączy kierunek upływu czasu z rozszerzaniem się Wszechświata) ${ }^{16}$. Wszystkie strzałki czasu wskazują ten sam kierunek.

14 S. Hawking, Krótka historia czasu, tłum. P. Amsterdamski, Warszawa 1993, s. 135. Prawa fizyki nie rozróżniają przeszłości i przyszłości. W życiu codziennym istnieje ogromna różnica między upływem czasu w przód i wstecz. Wyobraźmy sobie filiżankę z wodą spadającą ze stołu i pękającą na kawałki. Gdybyśmy sfilmowali to zdarzenie, to potem bez problemu możemy powiedzieć, czy film został wyświetlony w dobrym kierunku. Gdybyśmy puścili film w odwrotnym kierunku, to widzielibyśmy kawałki filiżanki zbierające się w całość. W rzeczywistości nie jest możliwa sytuacja powrotu do połączenia się rozbitych kawałków filiżanki.

15 K. Dzieliński, Fizycy potwierdzają strzałkę czasu, http://www.wykop.pl/ramka/1330651/ fizycy-potwierdzaja-strzalke-czasu (15.05.2015). Strzałka czasu jest pojęciem wprowadzonym do fizyki przez Arthura Eddingtona w 1927 roku. Oznacza ona kierunek upływu czasu, który zasadniczo jest tylko jeden - do przodu. Jednak w skali kwantowej nie jest to tak oczywiste, gdyż duża część zderzeń cząstek i innych oddziaływań pomiędzy nimi wygląda tak samo „od tyłu”. Teraz udało się jednak potwierdzić strzałkę czasu, a więc jego nieodwracalność - przynajmniej dla mezonów B.

16 P. Coveney, R. Highfield, Strzałka czasu. Jak rozwiązać największa tajemnicę nauki, tłum. P. Amsterdamski, Poznań 1997, s. 115. Druga zasada termodynamiki mówi o tym, że w układach zamkniętych nieuporządkowanie, czyli entropia dowolnego układu zamkniętego, zawsze wzrasta. Można to porównać do prawa Murphy’ego: „jeśli coś może pójść źle, to pójdzie”. 
Psychologiczna strzałka czasu (subiektywne poczucie upływu czasu) jest wyznaczona w mózgu człowieka przez strzałkę termodynamiczną (pamiętamy rzeczy w kierunku, w jakim wzrasta entropia). Nieporządek wzrasta z czasem, bo upływ czasu mierzymy w kierunku wzrostu nieporządku.

\section{Czas człowieka i człowiek w czasie}

Człowiek jest istotą temporalną. Temporalność należy do pierwotnego wyposażenia organizmów w ogóle. W procesach życia gatunku homo sapiens twierdzenie to nabiera specyficznego znaczenia $\mathrm{z}$ uwagi na temporalnie zorientowane świadomościowe doświadczenie, przeżywanie $\mathrm{i}$ interpretowanie egzystencji ${ }^{17}$.

Czas fizyki jest czasem obiektywnym i nieożywionym, a człowiek się w nim dzieje i staje, doświadcza go i interpretuje. Człowiek jest tym w przyrodzie, który w pewnym sensie zamyka czas w sobie, czasowi obiektywnemu nadaje znaczenie, a raczej odkrywa jego „subiektywny” charakter ${ }^{18}$. Czas człowieka (podmiotu osobowego) wpisuje się w czas obiektywny. Wszystko, co się człowiekowi przydarza i z nim się dzieje, dzieje się hic et nunc ${ }^{19}$.

W sensie społeczno-historycznym wiedza na temat ludzkiej temporalności jest klasyfikowana jako: przeszłość, teraźniejszość i przyszłość, a także w określeniach typu: teraz, przedtem i potem ${ }^{20}$. Czas egzystencji człowieka jest czymś, co Jan Paweł II określał jako przekraczanie „progu nadziei"21. Można zatem powiedzieć, że nie podmiot jest dla czasu choć jest w czasie - a czas jest dla podmiotu, który się poprzez niego staje i realizuje. W takim ujęciu „czas człowieka”22 nie jest ani rodzajem, ani

17 K. Popielski, Noopsychosomatyka. Propozycja nowego podejścia terapeutycznego, „Przegląd Psychologiczny" 42 (1999), nr 4, s. 17-41.

18 Z. Uchnast, Doświadczenie osobowe. Przedmiot jakościowej analizy personalistycznej, „Roczniki Psychologiczne” 5 (2002), s. 6-25.

19 J. Terelak, Człowiek i stres, Warszawa-Bydgoszcz 2008, s. 97.

20 K. Popper, J. Eccles, Das Ich und sein Gehirn, München-Zurich 1997, s. 26.

21 K. Wojtyła, Osoba i czyn, Lublin 2000, s. 74.

22 K. Popielski, Psychologia egzystencji. Wartości w życiu, Lublin 2008, s. 63. 
sposobem einsteinowskiego złudzenia, a raczej głębokim tłem doświadczania siebie. Jest to czas egzystencjalny, a nie fizykalny.

W naukach traktujących o poznaniu oddziela się czas obiektywny od czasu podmiotowo-subiektywnego i taktuje się je jako dwie rzeczywistości autonomiczne, ale komplementarne. Wyodrębnienie czasu podmiotowo-osobowego (subiektywnego) pozwala zgłębić rozwój osobowości człowieka i jego egzystencji. Człowiek może odnaleźć „swój czas", który pozwala mu odnieść się do siebie i otoczenia oraz do teraz, przedtem i potem ${ }^{23}$. Taka perspektywa czasu jest stosowana $\mathrm{w}$ terapii systemowej opartej na założeniu, że im głębiej człowiek doświadcza swojego czasu, tym pełniej w nim partycypuje, pełniej go przeżywa i uczestniczy w czasie od wiekuistym ${ }^{24}$. Czas człowieka (czas psychologiczny) to czas egzystencjalny, ma więcej znaczeń niż czas fizyczny, ponieważ osoba odbiera ten czas jako miarę swojego trwania. Przyszłość jest skierowana na to, co może nastąpić. Przeszłość jest formą rozliczenia z dokonanych działań, wyborów i decyzji, a teraźniejszość to punkt zwrotny między tym, co było, i tym, co będzie. Teraźniejszość „jest”, ale nie trwa, ona mija.

\section{Perspektywy postrzegania czasu}

Perspektywa postrzegania czasu przez człowieka odzwierciedla jego postawy, przekonania i wartości odnoszące się do czasu ${ }^{25}$. Pomaga również w ustaleniu odpowiedzi na pytanie, czy więcej czasu poświęca dana osoba na myśleniu o przeszłości, teraźniejszości czy przyszłości. Czy myśli są pozytywne, negatywne, radosne, smutne, pełne nadziei czy lęku.

Mówiąc o perspektywach postrzegania czasu przez człowieka można wskazać sześć perspektyw czasowych: dwie przeszłe (przeszłościowo-negatywna, przeszłościowo-pozytywna), dwie teraźniejsze (teraźniejsza

23 I. Boscolo, P. Bertrando, Die Zeiten der Zeit. Eine neue Perspektive in systemischer Therapie und Konsultation, Heidelberg 1994, s. 14.

24 K. Dąbrowski, W poszukiwaniu zdrowia psychicznego, Warszawa 1996, s. 38.

25 B. Liber, Mind time. The temporal factor in consciousness, Cambridge 2004, s. 77. 
fatalistyczna i teraźniejsza hedonistyczna) i dwie przyszłe (przyszła i przyszła transcendentalna) ${ }^{26}$.

Relację osoba-czas opisują dwa paradoksy czasu ${ }^{27}$. Pierwszy paradoks czasu: perspektywa postrzegania czasu głęboko oddziałuje na życie człowieka, chociaż rzadko zdaje on sobie z tego sprawę. Drugi paradoks czasu: umiarkowane nastawienie wobec przeszłości, teraźniejszości i przyszłości są oznaką zdrowia psychicznego, podczas gdy nastawienia skrajne wskazują na skłonności, które w przewidywalny sposób wiodą do niezdrowych wzorców życia.

\section{Szczęście a czas}

Czas daje człowiekowi okazje do odnalezienia szczęścia w przeszłości, teraźniejszości w przyszłości oraz w przyszłości transcendentalnej. Szczęścia można doznawać tylko w teraźniejszości. Szczęśliwe zdarzenie mogło wydarzyć się w przeszłości, ale wspomnienie to przywoływane jest w teraźniejszości. Często poszukując szczęścia w przeszłości lub przyszłości, nie widzimy teraźniejszości i szczęścia znajdującego się bezpośrednio przed nami ${ }^{28}$.

Człowiek, wracając do przeszłości lub wybiegając w przyszłość, nie jest w stanie żyć w teraźniejszości. Sonia Lyubomirsky opisała „ludzi szczęśliwych" jako osoby, które robią następujące rzeczy: pomagają innym, wyrażają wdzięczność za to, co posiadają, poświęcają czas rodzinie (relacjom towarzyskim), regularnie ćwiczą, mają optymistyczne nastawienie do przyszłości, wyznaczają sobie cele życiowe i je realizują oraz dobrze radzą sobie z problemami ${ }^{29}$. Przy czym każde z tych działań jest powiązane z określoną perspektywą postrzegania czasu.

26 P. Zimbardo, J. Boyd, Paradoks czasu, tłum. A. Cybulko, M. Zieliński, Warszawa 2014, s. 51.

27 P. Zimbardo, J. Boyd, Paradoks czasu, dz. cyt., s. 15.

28 Dalai Lama, The art of happiness. A handbook for living, New York 1999, s. 68.

29 P. Zimbardo, R. M. Sword, R. K. M. Sword, Siła czasu, tłum. A. Cybulko, Warszawa 2014, s. 212. 
Mimo że szczęście można odnaleźć w przeszłości, teraźniejszości oraz przyszłości, to istnieje wiele przeszkód w osiąganiu tego stanu. Ludzie szybko przyzwyczajają się do rzeczy pozytywnych, powoli zaś do stanów negatywnych, takich jak na przykład ból. Oznacza to, że okresy dobre przemijają szybko, podczas gdy złe okazują się długotrwałe.

\section{Metoda badań}

Przedmiotem przeprowadzonych badań jest relacja czas psychologiczny-szczęście (zadowolenie). Celem badań było ukazanie, jak perspektywa postrzegania czasu przez osoby badane wpływa na poczucie zadowolenia (szczęścia). Problem badawczy główny (PG) postawiony został następująco:

PG: Jak perspektywa postrzegania czasu wpływa na poczucie szczęścia (zadowolenia) u badanych osób?

P1: Jakie perspektywy postrzegania czasu dominują u badanych osób?

P2: Jakie jest subiektywne poczucie zadowolenia u badanych osób?

Badanie przeprowadzone zostało w lutym 2015 roku w Lublinie. Osoby badane to kobiety w wieku 25-30 lat. Badane pracują zawodowo i studiują na kierunkach nauk społecznych, są w dobrej relacji z innymi osobami (tab. 1). Mieszkają w promieniu $30 \mathrm{~km}$ od Lublina.

Tab. 1. Prezentacja osób badanych

\begin{tabular}{|c|c|c|c|c|c|c|}
\hline $\begin{array}{c}\text { Osoba } \\
\text { badana }\end{array}$ & Płeć & Wiek & $\begin{array}{c}\text { Miejsce } \\
\text { zamieszkania }\end{array}$ & $\begin{array}{c}\text { Sytuacja } \\
\text { rodzina }\end{array}$ & $\begin{array}{c}\text { Aktywność } \\
\text { zawodowa }\end{array}$ & $\begin{array}{c}\text { Relacje ja-inni; } \\
\text { inni-ja }\end{array}$ \\
\hline $\mathbf{1}$ & Kobieta & 27 & okolice Lublina & $\begin{array}{c}\text { Mieszka } \\
\text { z rodzicami }\end{array}$ & $\begin{array}{c}\text { Pracuje } \\
\text { i studiuje }\end{array}$ & $\begin{array}{c}\text { „lubię ludzi } \\
\text { i oni mnie lubią" }\end{array}$ \\
\hline 2 & Kobieta & 25 & okolice Lublina & $\begin{array}{c}\text { Mieszka } \\
\text { z rodzicami }\end{array}$ & $\begin{array}{c}\text { Pracuje } \\
\text { i studiuje }\end{array}$ & $\begin{array}{c}\text { mam wielu } \\
\text { znajomych } \\
\text { i dobrze mi z nimi” }\end{array}$ \\
\hline 3 & Kobieta & 28 & okolice Lublina & $\begin{array}{c}\text { Mieszka } \\
\text { z rodzicami }\end{array}$ & $\begin{array}{c}\text { Pracuje } \\
\text { i studiuje }\end{array}$ & $\begin{array}{c}\text { "przyjaciele i znajomi } \\
\text { są dla mnie ważni" }\end{array}$ \\
\hline 4 & Kobieta & 27 & okolice Lublina & $\begin{array}{c}\text { Mieszka } \\
\text { z rodzicami }\end{array}$ & $\begin{array}{c}\text { Pracuje } \\
\text { i studiuje }\end{array}$ & $\begin{array}{c}\text { "mam różnych } \\
\text { znajomych - } \\
\text { pomagamy sobie" }\end{array}$ \\
\hline
\end{tabular}




\begin{tabular}{|c|c|c|c|c|c|c|}
\hline $\begin{array}{c}\text { Osoba } \\
\text { badana }\end{array}$ & Płeć & Wiek & $\begin{array}{c}\text { Miejsce } \\
\text { zamieszkania }\end{array}$ & $\begin{array}{c}\text { Sytuacja } \\
\text { rodzina }\end{array}$ & $\begin{array}{c}\text { Aktywność } \\
\text { zawodowa }\end{array}$ & $\begin{array}{c}\text { Relacje ja-inni; } \\
\text { inni-ja }\end{array}$ \\
\hline 5 & Kobieta & 26 & okolice Lublina & $\begin{array}{c}\text { Mieszka } \\
\text { z rodzicami }\end{array}$ & $\begin{array}{c}\text { Pracuje } \\
\text { i studiuje }\end{array}$ & $\begin{array}{c}\text { „wolę być w domu”; } \\
\text { „nie przepadam za } \\
\text { osobami nie z rodziny” }\end{array}$ \\
\hline 6 & Kobieta & 28 & okolice Lublina & $\begin{array}{c}\text { Mieszka } \\
\text { z rodzicami }\end{array}$ & $\begin{array}{c}\text { Pracuje } \\
\text { i studiuje }\end{array}$ & $\begin{array}{c}\text { "mam znajomych } \\
\text { i są fajni" }\end{array}$ \\
\hline 7 & Kobieta & 25 & okolice Lublina & $\begin{array}{c}\text { Mieszka } \\
\text { z rodzicami }\end{array}$ & $\begin{array}{c}\text { Pracuje } \\
\text { i studiuje }\end{array}$ & $\begin{array}{c}\text { „mam przyjaciół } \\
\text { i znajomych, lubimy } \\
\text { robić coś razem” }\end{array}$ \\
\hline 8 & Kobieta & 29 & okolice Lublina & $\begin{array}{c}\text { Mieszka } \\
\text { z rodzicami }\end{array}$ & $\begin{array}{c}\text { Pracuje } \\
\text { i studiuje }\end{array}$ & $\begin{array}{c}\text { „mam kilku } \\
\text { znajomych"; } \\
\text { „wolę być w domu” }\end{array}$ \\
\hline
\end{tabular}

Źródło: opracowanie własne na podstawie badań własnych.

W przeprowadzonych badaniach zastosowano - jako metodę badań - studium indywidualnych przypadków z wykorzystaniem technik badawczych: badanie za pomocą testu, wywiad (rozmowa kierowana). Narzędziem badawczym był Kwestionariusz postrzegania czasu (The Zimbardo Time Perspective Inventory - ZTPI) autorstwa Philipa Zimbardo. Test składa się z 56 twierdzeń (tez), do których osoba badana ma się ustosunkować i odpowiedzieć: „Jak bardzo jest to dla mnie typowe lub prawdziwe?"30. W teście do oznaczania odpowiedzi wykorzystano pięciostopniową skalę z wartościami liczbowymi od 1 do 5 punktów. Przed wypełnieniem testu $\mathrm{z}$ osobami badanymi przeprowadzona została rozmowa, w której pytano o: wiek, miejsce zamieszkania, aktywność zawodową, relacje interpersonalne (ja-inni; inni-ja).

\section{Analiza i interpretacja wyników badań}

Poniżej przedstawiono odpowiedzi na pytania testowe testu ZTPI. Pytania testowe wraz z zaznaczonymi odpowiedziami przyporządkowane zostały - według podanego do testu klucza - do pięciu perspektyw postrzegania czasu przez badane osoby. W tabeli (tab. 2) znajdują się 
pytania wraz z odpowiedziami do przeszłej negatywnej perspektywy postrzegania czasu. Wartości liczbowe dla tej kategorii zostały podzielone przez liczbę 10, zgodnie z wymogami testu.

Tab. 2. Przeszła negatywna perspektywa postrzegania czasu - odpowiedzi badanych osób

\begin{tabular}{|c|c|c|c|c|c|c|c|c|c|}
\hline \multirow{2}{*}{$\begin{array}{l}\text { Numer } \\
\text { pytania }\end{array}$} & \multirow{2}{*}{ Treść pytania } & \multicolumn{8}{|c|}{ Badane osoby } \\
\hline & & 1 & 2 & 3 & 4 & 5 & 6 & 7 & 8 \\
\hline 4 & $\begin{array}{l}\text { Często myślę o tym, co powinienem } \\
\text { był zrobić w moim życiu inaczej. }\end{array}$ & 5 & 4 & 2 & 4 & 4 & 4 & 5 & 5 \\
\hline 5 & $\begin{array}{l}\text { Na moje decyzje wpływają } \\
\text { przede wszystkim otaczający mnie } \\
\text { ludzie i sprawy. }\end{array}$ & 5 & 4 & 3 & 2 & 1 & 5 & 5 & 4 \\
\hline 16 & $\begin{array}{l}\text { Bolesne doświadczenia z przeszłości } \\
\text { wciąż powracają w moich myślach. }\end{array}$ & 4 & 5 & 1 & 3 & 4 & 5 & 3 & 5 \\
\hline 22 & $\begin{array}{l}\text { Moja przeszłość nie szczędziła mi } \\
\text { krzywd i odrzucenia. }\end{array}$ & 5 & 4 & 4 & 3 & 4 & 5 & 4 & 4 \\
\hline 27 & $\begin{array}{l}\text { W przeszłości popełniałam błędy, } \\
\text { które chciałabym móc cofnąć. }\end{array}$ & 5 & 4 & 3 & 4 & 4 & 5 & 5 & 5 \\
\hline 33 & $\begin{array}{l}\text { Sprawy na ogół rzadko układają się } \\
\text { tak, jak tego oczekiwałam. }\end{array}$ & 2 & 4 & 3 & 3 & 4 & 5 & 3 & 4 \\
\hline 34 & $\begin{array}{l}\text { Ciężko mi zapomnieć nieprzyjemne } \\
\text { obrazy z mojej młodości. }\end{array}$ & 4 & 4 & 1 & 4 & 4 & 5 & 3 & 4 \\
\hline 35 & $\begin{array}{l}\text { Nawet kiedy cieszę się chwilą obecną, } \\
\text { coś zmusza mnie do porównywania } \\
\text { jej z podobnymi momentami } \\
\text { z przeszłości. }\end{array}$ & 4 & 2 & 2 & 2 & 1 & 4 & 3 & 5 \\
\hline 50 & $\begin{array}{l}\text { Myślę o niepowodzeniach, } \\
\text { które przytrafiły mi się w przeszłości. }\end{array}$ & 2 & 4 & 2 & 4 & 4 & 4 & 3 & 1 \\
\hline 54 & $\begin{array}{l}\text { Myślę o dobrych rzeczach, } \\
\text { które mnie w życiu ominęly. }\end{array}$ & 4 & 4 & 3 & 4 & 4 & 3 & 4 & 4 \\
\hline & Wynik ogólny & 40 & 39 & 24 & 33 & 34 & 45 & 38 & 41 \\
\hline
\end{tabular}

Źródło: opracowanie własne na podstawie badań własnych.

Tabela 3 zawiera wyniki (liczby) dla teraźniejszej hedonistycznej perspektywy postrzegania czasu. Wartości te zostały następnie podzielone przez 15 i zamieszczone $w$ tabeli 7. 
Tab. 3. Teraźniejsza hedonistyczna perspektywa postrzegania czasu - odpowiedzi badanych

\begin{tabular}{|c|c|c|c|c|c|c|c|c|c|}
\hline \multirow{2}{*}{$\begin{array}{l}\text { Numer } \\
\text { pytania }\end{array}$} & \multirow{2}{*}{ Treść pytania } & \multicolumn{8}{|c|}{ Badane osoby } \\
\hline & & 1 & 2 & 3 & 4 & 5 & 6 & 7 & 8 \\
\hline 1 & $\begin{array}{l}\text { Uważam, że spotykanie się z przyjaciół- } \\
\text { mi, aby się razem pobawić, to przyjem- } \\
\text { ność, która się należy każdemu. }\end{array}$ & 5 & 5 & 5 & 5 & 1 & 4 & 5 & 5 \\
\hline 8 & Działam pod wpływem impulsu. & 4 & 1 & 3 & 4 & 1 & 5 & 4 & 5 \\
\hline 12 & $\begin{array}{l}\text { Kiedy słucham mojej ulubionej muzyki, } \\
\text { często zupełnie tracę poczucie czasu. }\end{array}$ & 4 & 4 & 2 & 3 & 4 & 2 & 4 & 5 \\
\hline 17 & $\begin{array}{l}\text { Chcę przeżyć życie tak intensywnie, } \\
\text { jak to możliwe - dzień za dniem. }\end{array}$ & 4 & 4 & 5 & 4 & 4 & 3 & 5 & 4 \\
\hline 19 & $\begin{array}{l}\text { Idealnie byłoby przeżyć każdy dzień, } \\
\text { jak gdyby był ostatni w życiu. }\end{array}$ & 5 & 5 & 5 & 5 & 5 & 2 & 5 & 2 \\
\hline 23 & $\begin{array}{l}\text { Podejmuję decyzje pod wpływem } \\
\text { chwili. }\end{array}$ & 3 & 2 & 3 & 3 & 1 & 5 & 4 & 5 \\
\hline 26 & $\begin{array}{l}\text { Ważne jest, by czynić życie ekscytu- } \\
\text { jącym. }\end{array}$ & 5 & 4 & 3 & 4 & 4 & 3 & 5 & 3 \\
\hline 28 & $\begin{array}{l}\text { Uważam, że ważniejsze jest, by mieć } \\
\text { przyjemność z tego, co się robi, niż } \\
\text { z ukończenia pracy na czas. }\end{array}$ & 4 & 3 & 2 & 1 & 1 & 2 & 2 & 4 \\
\hline 31 & $\begin{array}{l}\text { Podejmowanie ryzyka sprawia, że moje } \\
\text { życie nie staje się nudne. }\end{array}$ & 5 & 2 & 3 & 4 & 1 & 2 & 3 & 3 \\
\hline 32 & $\begin{array}{l}\text { Ważniejsze jest dla mnie, by cieszyć } \\
\text { się podróżą przez życie, niż skupiać się } \\
\text { jedynie na jej celu. }\end{array}$ & 5 & 3 & 2 & 4 & 1 & 3 & 3 & 4 \\
\hline 42 & $\begin{array}{l}\text { Podejmuję ryzyko po to, aby w moim } \\
\text { życiu było więcej emocji. }\end{array}$ & 5 & 2 & 3 & 4 & 1 & 2 & 4 & 3 \\
\hline 44 & $\begin{array}{l}\text { Często kieruję się raczej sercem niż } \\
\text { głową. }\end{array}$ & 4 & 4 & 4 & 2 & 1 & 4 & 5 & 4 \\
\hline 46 & $\begin{array}{l}\text { Zauważam, że łatwo ulegam wpływowi } \\
\text { chwilowych emocji. }\end{array}$ & 5 & 5 & 2 & 2 & 4 & 4 & 4 & 4 \\
\hline 48 & $\begin{array}{l}\text { Wolę znajomych, którzy są raczej } \\
\text { spontaniczni niż przewidywalni. }\end{array}$ & 5 & 2 & 3 & 3 & 4 & 2 & 5 & 4 \\
\hline 55 & $\begin{array}{l}\text { Chcę, żeby osoby, z którymi pozostaję } \\
\text { w bliskiej zażyłości, miały swoje pasje. }\end{array}$ & 5 & 4 & 4 & 3 & 3 & 2 & 5 & 4 \\
\hline & Wynik ogólny & 68 & 50 & 49 & 51 & 36 & 41 & 43 & 59 \\
\hline
\end{tabular}

Źródło: opracowanie własne na podstawie badań własnych. 
Pytania dotyczące przyszłej perspektywy postrzegania czasu zawiera tabela 4. Podobnie jak wyżej, wartości wskazane przez badane osoby zostały zsumowane i podzielone, zgodnie z procedurą testową, przez 13.

Tab. 4. Przyszła perspektywa postrzegania czasu przez osoby badane - odpowiedzi badanych

\begin{tabular}{|c|c|c|c|c|c|c|c|c|c|}
\hline \multirow{2}{*}{$\begin{array}{l}\text { Numer } \\
\text { pytania }\end{array}$} & \multirow{2}{*}{ Treść pytania } & \multicolumn{8}{|c|}{ Badane osoby } \\
\hline & & 1 & 2 & 3 & 4 & 5 & 6 & 7 & 8 \\
\hline 6 & $\begin{array}{l}\text { Uważam, że każdego poranka należy } \\
\text { z wyprzedzeniem zaplanować dzień. }\end{array}$ & 1 & 3 & 2 & 3 & 4 & 4 & 3 & 2 \\
\hline 9 & $\begin{array}{l}\text { Jeśli moje zadania nie są wykonywane } \\
\text { na czas, nie martwię się tym. }\end{array}$ & 5 & 2 & 2 & 3 & 4 & 3 & 2 & 1 \\
\hline 10 & $\begin{array}{l}\text { Kiedy chcę coś osiągnąć, wyznaczam } \\
\text { cele i zastanawiam się nad konkretny- } \\
\text { mi krokami prowadzącymi do ich re- } \\
\text { alizacji. }\end{array}$ & 5 & 3 & 4 & 4 & 5 & 1 & 4 & 3 \\
\hline 13 & $\begin{array}{l}\text { Dotrzymywanie wyznaczonych ter- } \\
\text { minów oraz realizowanie niezbęd- } \\
\text { nych działań ma zawsze pierwszeństwo } \\
\text { przed bieżącymi rozrywkami. }\end{array}$ & 4 & 4 & 5 & 4 & 4 & 3 & 3 & 3 \\
\hline 18 & $\begin{array}{l}\text { Martwi mnie, kiedy spóźniam się } \\
\text { na spotkanie. }\end{array}$ & 4 & 4 & 5 & 4 & 4 & 5 & 3 & 5 \\
\hline 21 & $\begin{array}{l}\text { Swoje obowiązki wobec przyjaciół } \\
\text { i przełożonych wypełniam na czas. }\end{array}$ & 5 & 4 & 5 & 4 & 4 & 5 & 4 & 4 \\
\hline 24 & $\begin{array}{l}\text { Zamiast rozplanowywać każdy dzień, } \\
\text { przyjmuję go takim, jaki jest. }\end{array}$ & 4 & 3 & 3 & 4 & 1 & 5 & 4 & 5 \\
\hline 30 & $\begin{array}{l}\text { Przed podjęciem decyzji robię rachu- } \\
\text { nek zysków i strat. }\end{array}$ & 4 & 3 & 2 & 3 & 4 & 2 & 3 & 3 \\
\hline 40 & $\begin{array}{l}\text { Kończę swoje projekty na czas, posu- } \\
\text { wając się do przodu w stałym tempie. }\end{array}$ & 4 & 3 & 4 & 4 & 4 & 3 & 3 & 4 \\
\hline 43 & Robię listy spraw do załatwienia. & 3 & 3 & 1 & 4 & 1 & 5 & 4 & 4 \\
\hline 45 & $\begin{array}{l}\text { Jestem w stanie powściągnąć swoje za- } \\
\text { chcianki, kiedy wiem, że trzeba wyko- } \\
\text { nać jakąś pracę. }\end{array}$ & 5 & 5 & 5 & 4 & 4 & 1 & 4 & 4 \\
\hline 51 & $\begin{array}{l}\text { Wytrwale pracuję nad trudnymi, nud- } \\
\text { nymi zadaniami, jeśli pozwolą mi iść } \\
\text { do przodu. }\end{array}$ & 5 & 4 & 3 & 4 & 4 & 4 & 3 & 3 \\
\hline
\end{tabular}




\begin{tabular}{|c|l|c|c|c|c|c|c|c|c|}
\hline \multirow{2}{*}{$\begin{array}{l}\text { Numer } \\
\text { pytania }\end{array}$} & \multicolumn{1}{|c|}{ Treść pytania } & \multicolumn{7}{|c|}{ Badane osoby } \\
\cline { 2 - 13 } & \multicolumn{1}{|c|}{$\begin{array}{l}\text { Często powtarzam: „Robota nie zając }- \\
\text { nie ucieknie”. }\end{array}$} & 5 & 2 & 4 & 1 & 1 & 2 & 2 & 3 \\
\hline & Wynik ogólny & 54 & 43 & 45 & 46 & 44 & 43 & 42 & 44 \\
\hline
\end{tabular}

Źródło: opracowanie własne na podstawie badań własnych.

Wyniki dla przeszłej pozytywnej perspektywy czasu umieszczone zostały w tabeli 5. Uzyskane dane liczbowe podzielone zostały przez 9.

Tab. 5. Przeszła pozytywna perspektywa postrzegania - odpowiedzi badanych

\begin{tabular}{|c|l|c|c|c|c|c|c|c|c|}
\hline \multirow{2}{*}{$\begin{array}{c}\text { Numer } \\
\text { pytania }\end{array}$} & \multicolumn{7}{|c|}{ Treść pytania } & \multicolumn{7}{|c|}{ Badane osoby } \\
\cline { 3 - 10 } & \multicolumn{1}{|c|}{$\begin{array}{l}\text { Znane z dzieciństwa widoki, dźwięki } \\
\text { i zapachy często wywołują u mnie falę } \\
\text { cudownych wspomnień. }\end{array}$} & 4 & 5 & 4 & 4 & 1 & 4 & 4 & 5 \\
\hline 7 & $\begin{array}{l}\text { Myślenie o mojej przeszłości sprawia } \\
\text { mi przyjemność. }\end{array}$ & 4 & 4 & 5 & 3 & 1 & 2 & 4 & 1 \\
\hline 11 & $\begin{array}{l}\text { Kiedy się zastanowię, z mojej przeszło- } \\
\text { ści przypomina mię znacznie więcej } \\
\text { zdarzeń dobrych niż złych. }\end{array}$ & 4 & 4 & 4 & 3 & 1 & 2 & 3 & 2 \\
\hline 15 & $\begin{array}{l}\text { Lubię słuchać opowieści o tym, jak } \\
\text { było w „starych, dobrych czasach”. }\end{array}$ & 1 & 5 & 3 & 3 & 4 & 2 & 3 & 2 \\
\hline 20 & $\begin{array}{l}\text { Latwo przychodzą mi do głowy szczęś- } \\
\text { liwe wspomnienia z dobrych czasów. }\end{array}$ & 4 & 4 & 4 & 4 & 4 & 5 & 4 & 2 \\
\hline 25 & $\begin{array}{l}\text { Przeszłość wiąże się ze zbyt wielo- } \\
\text { ma nieprzyjemnymi wspomnieniami, } \\
\text { do których niechętnie wracam. }\end{array}$ & 4 & 4 & 1 & 5 & 1 & 5 & 3 & 4 \\
\hline 29 & $\begin{array}{l}\text { Bywa, że zaczynam czuć nostalgię } \\
\text { za moim dzieciństwem. }\end{array}$ & 2 & 3 & 2 & 3 & 1 & 2 & 3 & 2 \\
\hline 41 & $\begin{array}{l}\text { Zauważyłem, że wyłączam się, kiedy } \\
\text { członkowie mojej rodziny zaczynają } \\
\text { rozmawiać o tym, jak to kiedyś bywało. }\end{array}$ & 2 & 2 & 2 & 2 & 1 & 2 & 2 & 3 \\
\hline 49 & $\begin{array}{l}\text { Lubię rodzinne rytuały i tradycje, które } \\
\text { regularnie się powtarzają. }\end{array}$ & 2 & 5 & 4 & 4 & 4 & 3 & 5 & 2 \\
\hline & \begin{tabular}{l} 
Wynik ogólny \\
\hline
\end{tabular} & 27 & 36 & 29 & 31 & 18 & 27 & 31 & 23 \\
\hline
\end{tabular}

Źródło: opracowanie własne na podstawie badań własnych. 
Ostatnia z wyróżnionych perspektyw postrzegania czasu - teraźniejsza fatalistyczna perspektywa - opisana została w tabeli 6 . Uzyskane wartości liczbowe zostały podzielone przez 9 i podane w tabeli 7.

Tab. 6. Teraźniejsza fatalistyczna perspektywa postrzegania czasu - odpowiedzi badanych

\begin{tabular}{|c|c|c|c|c|c|c|c|c|c|}
\hline \multirow{2}{*}{$\begin{array}{l}\text { Numer } \\
\text { pytania }\end{array}$} & \multirow{2}{*}{ Treść pytania } & \multicolumn{8}{|c|}{ Badane osoby } \\
\hline & & 1 & 2 & 3 & 4 & 5 & 6 & 7 & 8 \\
\hline 3 & $\begin{array}{l}\text { W moim życiu wiele zależy od prze- } \\
\text { znaczenia. }\end{array}$ & 4 & 2 & 3 & 3 & 4 & 5 & 3 & 3 \\
\hline 14 & $\begin{array}{l}\text { Ponieważ, co ma być, to będzie, więc } \\
\text { nie ma wielkiego znaczenia, jakie } \\
\text { podejmę działania. }\end{array}$ & 1 & 2 & 2 & 2 & 1 & 3 & 2 & 3 \\
\hline 35 & $\begin{array}{l}\text { Konieczność planowania } \\
\text { i kontrolowania prowadzonych } \\
\text { przez mnie działań odbiera mi całą } \\
\text { przyjemność z pracy. }\end{array}$ & 4 & 2 & 2 & 2 & 1 & 3 & 4 & 5 \\
\hline 37 & $\begin{array}{l}\text { Świat zmienia się tak szybko, że tak } \\
\text { naprawdę nie da się nic zaplanować } \\
\text { na przyszłość. }\end{array}$ & 4 & 5 & 2 & 2 & 1 & 5 & 4 & 4 \\
\hline 38 & $\begin{array}{l}\text { Moją ścieżkę życiową wyznaczają siły, } \\
\text { na które nie mam wpływu. }\end{array}$ & 4 & 4 & 2 & 1 & 4 & 5 & 3 & 3 \\
\hline 39 & $\begin{array}{l}\text { Nie ma sensu martwić się o przyszłość, } \\
\text { bo i tak nie można nic z nią zrobić. }\end{array}$ & 1 & 2 & 2 & 1 & 1 & 5 & 3 & 4 \\
\hline 47 & $\begin{array}{l}\text { Dzisiejsze życie jest zbyt skomplikowa- } \\
\text { ne, wolałabym żyć w dawnych czasach, } \\
\text { kiedy wszystko było proste. }\end{array}$ & 2 & 5 & 2 & 2 & 1 & 4 & 3 & 4 \\
\hline 52 & $\begin{array}{l}\text { Wolę dziś wydać zarobione pieniądze } \\
\text { na przyjemności, niż odkładać je } \\
\text { z myślą o bezpiecznym jutrze. }\end{array}$ & 5 & 3 & 2 & 3 & 1 & 5 & 2 & 3 \\
\hline 53 & $\begin{array}{l}\text { Często bardziej opłaca się mieć } \\
\text { szczęście, niż ciężko pracować. }\end{array}$ & 2 & 4 & 3 & 3 & 1 & 4 & 4 & 3 \\
\hline & Wynik ogółem & 27 & 27 & 20 & 19 & 15 & 39 & 28 & 32 \\
\hline
\end{tabular}

Źródło: opracowanie własne na podstawie badań własnych. 
Tab. 7. Prezentacja wyników badań - po opracowaniu według klucza zamieszczonego w teście ZTPI - dla poszczególnych osób i perspektyw postrzegania czasu

\begin{tabular}{|c|c|c|c|c|c|}
\hline $\begin{array}{c}\text { Osoba } \\
\text { badana }\end{array}$ & $\begin{array}{c}\text { Przeszła } \\
\text { negatywna } \\
\text { perspektywa } \\
\text { postrzegania } \\
\text { czasu (liczba) }\end{array}$ & $\begin{array}{c}\text { Teraźniejsza } \\
\text { hedonistyczna } \\
\text { perspektywa } \\
\text { postrzegania } \\
\text { czasu (liczba) }\end{array}$ & $\begin{array}{c}\text { Przyszła } \\
\text { perspektywa } \\
\text { postrzegania } \\
\text { czasu (liczba) }\end{array}$ & $\begin{array}{c}\text { Przeszła } \\
\text { pozytywna } \\
\text { perspektywa } \\
\text { postrzegania } \\
\text { czasu (liczba) }\end{array}$ & $\begin{array}{c}\text { Teraźniejsza } \\
\text { fatalistyczna } \\
\text { perspektywa } \\
\text { postrzegania } \\
\text { czasu (liczba) }\end{array}$ \\
\hline $\mathbf{1}$ & 4,0 & 4,5 & 4,1 & 3,0 & 3,0 \\
\hline $\mathbf{2}$ & 3,9 & 3,3 & 3,3 & 4,0 & 3,0 \\
\hline $\mathbf{3}$ & 2,4 & 3,2 & 3,4 & 3,2 & 2,2 \\
\hline $\mathbf{4}$ & 3,3 & 3,4 & 3,5 & 3,4 & 2,1 \\
\hline $\mathbf{5}$ & 3,4 & 2,4 & 3,3 & 2,0 & 1,6 \\
\hline $\mathbf{6}$ & 4,5 & 2,7 & 3,3 & 3,0 & 4,3 \\
\hline $\mathbf{7}$ & 3,8 & 2,8 & 3,2 & 3,4 & 3,0 \\
\hline $\mathbf{8}$ & 4,1 & 2,6 & 3,3 & 2,5 & 3,5 \\
\hline
\end{tabular}

Źródło: opracowanie własne na podstawie badań własnych.

Największe wartości liczbowe związane są z teraźniejszą hedonistyczną perspektywą postrzegania czasu, przeszłą negatywną i przyszłą perspektywą postrzegania czasu (Osoba 1). W przypadku innych badanych osób widoczne jest zróżnicowanie perspektyw postrzegania czasu. I tak, odpowiedzi Osoby 5 mają najniższe wartości liczbowe dla perspektyw czasowych teraźniejszej fatalistycznej i przeszłej pozytywnej.

Badane osoby poproszone zostały o wskazanie - na pięciostopniowej skali - ich subiektywnego poczucia zadowolenia (tab. 8). Prawie połowa badanych (trzy kobiety) zaznaczyła bardzo wysokie zadowolenie z życia, trzy kobiety zaznaczyły duże zadowolenie, czyli 75 proc. badanych jest szczęśliwych. Dwie pozostałe badane wypowiedziały się: „nie mogę powiedzieć" oraz przez zaznaczenie niskiego zadowolenia z życia.

Tab. 8. Subiektywne poczucie zadowolenia (szczęścia) u badanych osób

\begin{tabular}{|c|c|c|c|c|c|}
\hline $\begin{array}{c}\text { Osoba } \\
\text { badana }\end{array}$ & $\begin{array}{c}\text { Duże } \\
\text { zadowolenie }\end{array}$ & $\begin{array}{c}\text { Bardzo duże } \\
\text { zadowolenie }\end{array}$ & $\begin{array}{c}\text { Nie potrafię } \\
\text { powiedzieć }\end{array}$ & $\begin{array}{c}\text { Niskie } \\
\text { zadowolenie }\end{array}$ & $\begin{array}{c}\text { Bardzo niskie } \\
\text { zadowolenie }\end{array}$ \\
\hline 1 & & + & & & \\
\hline 2 & + & & & & \\
\hline
\end{tabular}




\begin{tabular}{|c|c|c|c|c|c|}
\hline $\begin{array}{c}\text { Osoba } \\
\text { badana }\end{array}$ & $\begin{array}{c}\text { Duże } \\
\text { zadowolenie }\end{array}$ & $\begin{array}{c}\text { Bardzo duże } \\
\text { zadowolenie }\end{array}$ & $\begin{array}{c}\text { Nie potrafię } \\
\text { powiedzieć }\end{array}$ & $\begin{array}{c}\text { Niskie } \\
\text { zadowolenie }\end{array}$ & $\begin{array}{c}\text { Bardzo niskie } \\
\text { zadowolenie }\end{array}$ \\
\hline 3 & & + & & & \\
\hline 4 & & + & & + & \\
\hline 5 & & & & & \\
\hline 6 & + & & & & \\
\hline 7 & + & & & & \\
\hline 8 & & & + & & \\
\hline
\end{tabular}

Źródło: opracowanie własne na podstawie badań własnych.

\section{Podsumowanie}

Przeprowadzona analiza wyników badań daje podstawy do wysunięcia następujących wniosków:

- Badane osoby - 75 proc. - są zadowolone lub bardzo zadowolone.

- Osoby o bardzo dużym poziomie zadowolenia mają teraźniejszą hedonistyczną i przyszłą perspektywę postrzegania czasu.

- Duże zadowolenie jest udziałem badanych z przeszłej (negatywnej i pozytywnej) perspektywy postrzegania czasu i przyszłej perspektywy postrzegania czasu. Dla tych osób teraźniejsza perspektywa czasowa wydaje się mieć mniejsze znaczenie.

- Osoba 8 nie potrafiła ocenić zadowolenia (szczęścia). Jej perspektywa postrzegania czasu wydaje się związana z teraźniejszą fatalistyczną perspektywą czasową i z przeszłą negatywną perspektywą czasową - stąd trudność w ocenie poczucia zadowolenia.

- Niskie zadowolenie dotyczy Osoby 5. Z perspektywy postrzegania czasu jest ona „zakotwiczona” w teraźniejszej fatalistycznej perspektywie czasowej i przeszłej negatywnej perspektywie czasowej, przy jednoczesnym ukierunkowaniu na przyszłą czasową perspektywę postrzegania czasu.

Wynika z tego, że perspektywy postrzegania czasu korelują z poczuciem zadowolenia u badanych osób. Osoby zadowolone są w teraźniejszej i przyszłej perspektywie postrzegania czasu, a także perspektywie przeszłej (pozytywnej), co odpowiada opisowi „ludzi szczęśliwych”. 


\section{Bibliografia}

20 marca międzynarodowym dniem szczęścia, PPM Blog, http://przegladpm.blogspot. com/2014/03/20-marca-miedzynarodowym-dniem-szczescia.html (15.05.2015).

Białkowski G., Stare i nowe drogi fizyki. Fizyka dnia dzisiejszego, Warszawa 1985.

Boscolo I., Bertrando P., Die Zeiten der Zeit.Eine neue Perspektive in systemischer Therapie und Konsultation, Heidelberg 1994.

Cooper L., Istota i struktura fizyki, tłum. J. Kozubowski i in., Warszawa 1985.

Coveney P., Highfield R., Strzałka czasu. Jak rozwiązać największą tajemnicę nauki, tłum. P. Amsterdamski, Poznań 1997.

Dalai Lama, The art of happiness. A handbook for living, New York 1999.

Dąbrowski K., W poszukiwaniu zdrowia psychicznego, Warszawa 1996.

Dzieliński K., Fizycy potwierdzają strzałkę czasu, http://www.wykop.pl/ramka/1330651/ fizycy-potwierdzaja-strzalke-czasu (15.05.2015).

Haidt J., Szczęście. Od mądrości starożytnych po koncepcje współczesne, tłum. A. Nowak, Gdańsk 2007.

Hawking S., Krótka historia czasu, tłum. P. Amsterdamski, Warszawa 1993.

Encyklopedia filozofii, t. 1, red. T. Honderich, tłum. J. Łoziński, Poznań 1995.

Kaczor M., Etyczno-społeczny wymiar pojęcia szczęście na podstawie definicji słownikowych, [w:] Szczęście w wymiarze pedagogiczno-socjologicznym, red. E. Kowalska, P. Prufer, M. Kowalski, Kraków 2014, s. 27-39.

Layard R., Why happiness should be a global priority, http://www.huffingtonpost.co.uk/ richard-layard/why-happiness-should-be-a-global-priority_b_2900256.html (16.05.2015).

Liber B., Mind time. The temporal factor in consciousness, Cambridge 2004.

Lord C., Arystoteles, [w:] Historia filozofii politycznej, red. L. Strauss, J. Cropsey, Warszawa 2010 , s. $125-139$.

Popielski K., Noopsychosomatyka. Propozycja nowego podejścia terapeutycznego, „Przegląd Psychologiczny" 42 (1999), nr 4, s. 17-41.

Popielski K., Psychologia egzystencji. Wartości w życiu, Lublin 2008.

Popper K., Eccles J., Das Ich und sein Gehirn, München-Zurich 1997.

Resolution adopted by the General Assembly on 28 June 2012, General Assembly, A/RES/66/281, http://www.un.org/ga/search/view_doc.asp?symbol=A/RES/66/281 (15.05.2015). 
Słownik języka polskiego, t. 3, red. M. Szymczak, Warszawa 1995.

Szczególna i Ogólna Teoria Względności, iWiedza, http://www.iwiedza.net/wiedza/136. html (15.05.2015).

Tatarkiewicz W., O szczęściu, Warszawa 1962.

Tatarkiewicz W., Historia filozofi, Warszawa 2005.

Terelak J., Człowiek i stres, Warszawa-Bydgoszcz 2008.

Termodynamiczna strzałka czasu, Eduteka.pl, http://encyklopedia.eduteka.pl/wiki/Ter modynamiczna_strza\%C5\%82ka_czasu (15.05.2015).

Uchnast Z., Doświadczenie osobowe. Przedmiot jakościowej analizy personalistycznej, „Roczniki Psychologiczne” 5 (2002), s. 6-25.

Uniwersalny słownik języka polskiego, t. 3, red. S. Dubisz, Warszawa 3003.

Williamson M., Improving wellbeing schould be our global priority, http://www.huffing tonpost.co.uk/dr-mark-williamson/enhancing-human-wellbeing_b_3887498.html (12.02.2016).

Wojtyła K., Osoba i czyn, Lublin 2000.

Zimbardo P., Boyd J., Paradoks czasu, tłum. A. Cybulko, M. Zieliński, Warszawa 2014.

Zimbardo P., Sword R. M., Sword R. K. M., Siła czasu, tłum. A. Cybulko, Warszawa 2014. 